\section{The investigation of organizational cynism and organizational commitment perceptions of academic staff at higher education institutions offering sports education}

\author{
Kadir Çalışkan ${ }^{2}$ \\ Sümmani Ekici ${ }^{3}$
}

\begin{abstract}
The purpose of this study is to investigate the relationship between organizational cynism perception levels and organizational commitment levels of the academic staff from sports sciences departments at higher education institutions. The population of the study consists of all academic staff from sports sciences departments at higher education institutions and 396 sets of data ( $\mathrm{n}=291$ male, $\mathrm{n}=105$ female) were collected from the academic staff.

To determine the organizational cynism levels of the academic staff, an 13-item scale "Organizational Cynism Scale," which was developed by Brandes, Dhalwadkar and Dean (1999) was utilized in the study. The reliability score was calculated as $\alpha=0.93$ and the Turkish adaptation of the scale was also performed by Kalağan (2009). Besides, in order to determine the organizational commitment levels of the participants, an 18-item scale "Organizational Commitment Scale", which was developed by Allen and Meyer (1996) and used in Turkish format by Belli (2014), was utilized in the study. The data were analyzed with SPSS 20.0 packet program. In addition to descriptive statistics, t-
\end{abstract}

Özet

Bu araştırma, spor eğitimi veren yükseköğretim kurumlarındaki öğretim elemanlarının örgütsel sinizm algiları ile örgütsel bağlllıkları arasındaki etkileşimi belirlemek amacıyla yapılmıştır. Araştırmanın evrenini, Türkiye'de spor eğitimi veren yükseköğretim kurumlarındaki öğretim elemanları oluşturmuş ve 396 ( $\mathrm{n}=291$ erkek, $\mathrm{n}=105$ kadın) akademisyene ulaşılmıştır.

Örgütsel sinizm algısının belirlenmesine yönelik Brandes, Dhalwadkar ve Dean (1999) tarafindan geliştirilmiş ve Kalağan (2009) tarafindan geçerlilik-güvenirliği $(\alpha=0.93)$ ve Türkçe'ye uyarlaması yapılmış olan 13 maddelik "Örgütsel Sinizm Ölçeği” kullanılmıştır. Örgütsel bağllık düzeylerini belirlemek amaciyla da Allen ve Meyer'in (1996) geliştirdikleri ve Belli (2014) tarafindan Türkçe formunun kullanıldığı 18 maddeden oluşan "Örgütsel Bağllik Ölçeği”’nden yararlanılmıştır.

Veriler SPSS 20,0 paket programı araciluğıla analiz edilmiştir. Tanımlayıcı istatistiklerin yanında katulımcıların demografik değişkenlerine göre farklılıklarını tespit etmek için t-testi ve tek yönlü varyans analizi (ANOVA) kullanılmıştır. ANOVA testi sonucunda anlamli farkliliğın hangi gruptan kaynaklandığını görmek için

\footnotetext{
${ }^{1}$ Bu çalışma; Spor Eğitimi Veren Yükseköğretim Kurumlarındaki Öğretim Elemanlarının Örgütsel Sinizm Algıları ile Örgütsel Bağllıklarının Araştırılması adlı yüksek lisans tezinden özetlenmiştir.

2 Arş .Gör., Bitlis Eren Üniversitesi, Beden Eğitimi ve Spor Yüksekokulu, Spor Yöneticiliği Bölümü, kcaliskan@hotmail.com

${ }^{3}$ Doç. Dr., Muğla S1tkı Koçman Üniversitesi, Spor Bilimleri Fakültesi, Spor Yöneticiliği Bölümü, ekicis@gmail.com
} 
Çalışkan, K., \& Ekici, S. (2017). Spor eğitimi veren yükseköğretim kurumlarındaki öğretim elemanlarının örgütsel sinizm algıları ile örgütsel bağlllıklarının araştırllması. Journal of Human Sciences, 14(2), 1674-1689. doi: $10.14687 /$ ihs.v14i2.4485

tests (Independent $\mathrm{t}$-Test) and analysis of variance (One-Way ANOVA) were carried out in order to identify the differences in terms of demographic variables. Tukey HSD test was utilized to specify the groups from which significant differences were derived and Pearson correlation test was also used in order to examine the relationship between variables. All findings were considered according to $\mathrm{p}<0.05$ significance level in the study.

The results of the study suggest that the organizational commitment levels of the academic staff are medium-degree and their organizational cynism perceptions are low. In terms of organizational cynism, some significant differences were found out regarding the length of time spent working at that institution, administrative function and change of title variables. On the other hand, there were also some significant differences in variables like gender, age and the length of time spent at that institution in terms of organizational commitment as well as administrative function and change of title variables, those being similar to the results of organizational cynism. Additionally, it was found out that there existed medium-degree and negative relationship between organizational cynism and organizational commitment.

Keywords: Sports, Cynism, Organizational Cynism, Organizational Commitment.

(Extended English abstract is at the end of this document)
Tukey HSD testinden yararlanılmıştır. Değişkenler arası ilişkiyi sorgulamak için ise Pearson korelasyon analizinden faydalanılmıştır. Araştırmada tüm bulgular $\mathrm{p}<0.05$ anlamlilik düzeyine göre dikkate alınmıştır.

Araştırmanın sonuçlarına göre; öğretim elemanlarının örgütsel sinizmleri düşük, örgütsel bağllilk hisleri ise orta seviyede çıkmıştur. Örgütsel sinizmde ve çeşitli alt boyutlarda; kurumdaki hizmet süresi, idari görev ve ünvan değişkenlerinde farkllilklar tespit edilmiş, örgütsel bağlllıkta ise farklllıklar yine idari görev ve ünvan değişkenlerinde görülmekle birlikte cinsiyet, yaş ve meslekteki hizmet süresi değişkenlerinde ortaya çıkmıştır. Ayrıca örgütsel sinizm ile örgütsel bağllitk arasında orta düzeyde negatif yönlü bir ilişkinin varlığı belirlenmiştir.

Anahtar Kelimeler: Spor; Sinizm; Örgütsel Sinizm; Örgütsel Bağlllik.

\section{GİRIŞ}

Örgütlerin temel öğesi insanlardır. Ortak ya da benzer amaçlar doğrultusunda bir araya gelen insan toplulukları örgütü oluştururlar. Nasıl ki insanlar davranışları ile yaşamlarını sürdürmekteyse örgütler de yaşamlarını üyelerinin davranışları ile sağlarlar (Başaran, 1991). Neoklasik yönetim yaklaşımının temellerinin atıldığ1 1930'lu yıllarda Hawthorne deneyleriyle görülmüştür ki, çalışanların iş yerlerindeki mutlulukları, motive edilmeleri, olumlu bir örgüt iklimi içerisinde çalışmalarının sağlanması, onların iş tatmin düzeylerini ve üretkenliğini artırmakta, gruplar arası etkileşim ve iş birliği ile alınan çıktıların değeri hem nicel hem de nitel yönden yükselmektedir. Çalışanların davranışları ile örgütün genel performansının doğru orantıda oluşu dikkate aldındığında söz konusu olumlu havanın bozulması, iletişim sorunlarının artmasına, geçimsizlik, disiplinin bozulması, çatışma ve en nihayetinde işten ayrılma niyetinin oluşmasına yol açabilmektedir ( $\mathrm{T}$. Bolat, Seymen, O. Bolat ve Erdem, 2009). 
Çalışkan, K., \& Ekici, S. (2017). Spor eğitimi veren yükseköğretim kurumlarındaki öğretim elemanlarının örgütsel sinizm algıları ile örgütsel bağlılıklarının araştırlması. Journal of Human Sciences, 14(2), 1674-1689. doi: $10.14687 /$ ihs.v14i2.4485

Çalıştıkları kurumun ücret, terfi ya da ödüllendirme gibi konularda adaletten yoksun olduğuna inanma, yetenek ve becerilerin sunulmasında karşılaşılan engeller, yoğun çalışma saatleri, iletişimsizlik, rol belirsizliği ya da iltimas gibi işgörenin yıpranmasına yol açan eylemler; çalışanların bağı bulunduğu örgüte karşı beslediği negatif duygular olarak tanımlanan örgütsel sinizme yol açabilmektedir (Özgener, Öğüt ve Kaplan, 2008, s. 57).

Dean, Brandes ve Dharwadkar (1998) örgütsel sinizmi; bireyin çalıştğı örgüte yönelik duyduğu olumsuz düşünce, duygu ve eğilim olarak tanımlamaktadır. Bu tanıma bakttğımızda üç boyutun bir arada bulunduğu görülmektedir. Bunlar;

- Örgütün dürüstlükten uzak olduğuna inanma,

- Örgüte karşı duyulan olumsuz duygular,

- Örgüte yönelik olarak oluşturulan olumsuz inanış ve duygularla tutarlllık arz eden davranışlardır.

Örgütsel sinizm; bilişsel, duyuşsal ve davranışsal sinizm olmak üzere üç boyuttan oluşmaktadır. Bilişsel boyut, çalışanların örgütün bütünlükten yoksun olduğuna inançlarını ifade etmektedir. Örgüt içerisindeki bireyler; adalet, dürüstlük, samimiyet gibi olguların olmadığına, etik dışı davranışların sıradanlaştığına ve insanların güvenilmez oldukları inancını taşırlar (Dean ve diğerleri, 1998).

Duyuşsal boyutta bireyler bağlı oldukları örgütlere karşı duygusal açıdan olumsuz hislere sahiptir. Nefret, kin, öfke gibi negatif hisleri taşımakta, hatta kurumlarından utanç duyacak kadar olumsuzluk içerisinde olabilirler (Kalağan, 2009).

Davranışsal boyutta ise sinikler, inançları ve duygularını davranışa dönüştürmektedir. Hatta birbirlerine bakarak, gülerek de duygu ve düşüncelerini ifade etme yoluna gidebilirler (Özgener, 2008'den akt. Çetinkaya, 2014).

Yanlış yönetilen stratejik çabalar, aşırı stres ve iş yükü, kişisel beklentilerin karşılanmaması, yetersiz destek, terfilerde adaletsizlik, amaç çatışması, örgütsel karmaşıklık, etkisiz karar alım mekanizmaları, iletişimsizlik, psikolojik sözleşme ihlalleri, işten çıkarma örgütsel sinizmin nedenleri olarak görülmektedir (Akman, 2013, s. 15). Efeoğlu ve İplik’e (2011) göre ortaya çıkış sebepleri arasinda samimiyet, adalet, dürüstlük, güven gibi temel beklentilerin zedelenmesi görülmüsstür. Ayrıca sinikler, yönetimin örgüt içinde dürüstlük sergilemediğini, diğer üyelerin kendilerinden faydalanacağını ve kendilerinin haksızlığa uğrayacağını vurgulamaktadırlar (Eaton, 2000).

$\mathrm{Bu}$ durumun aksi de söz konusu olabilir. İşgörenlerin bağlllı̆̆1, örgütsel başarıya ulaşma yolunda temel faktörlerden biri kabul edilmektedir. Çalışanların bağlllık düzeylerini yükseltmek örgüte yön veren kişilerce üzerinde durulması gereken bir konudur. Çünkü sistemin temel taşı olan insanlar, bağlllık düzeyi yükseldikçe problem üreten değil problem çözen çalışan haline dönüşürler (Homayouni, 2014). Ayrıca Balay (2000), çalışanların örgütsel bağllılk duygularının yüksek olmasının hem çalışanın bireysel performansını olumlu yönde etkileyerek gelişimine destek olduğunu hem de örgütsel yarar sağladığını dile getirmiştir.

Örgütsel bağlllı̆̆ın temelinde 'sadakat' ve 'örgütte kalma eğilimi' vardır. Sadakat işgörenin örgütle olan özdeşleşmesi ve sorumluluk duygusu ile ortaya çıkar. Sadakat çalışanın örgüt içerisindeki mutluluğu ve iş tatmini ile doğru ilişkili olarak değişebilir. Örneğin istek ve beklentilerinin karşılandığını düşünen işgörenin sadakati yüksek olurken, duygusal olarak tatmin olmayan çalışanın sadakati düşük olabilir. Örgütte kalma eğilimi ise kurumda kalma niyeti olarak açıklanabilir. Tatmin edildiğini düşünen çalışan örgütün parçası olmaktan memnuniyet duyar ve verimliliğini en yüksek düzeyde kuruma yansıtmaya çalışırak, kalıcı olmayı hedefler. (Uygur, 2009).

Allen ve Meyer (1990), örgütsel bağlllığ1 “duygusal”, “devamlllık” ve “normatif” olarak üç boyutta değerlendirmişlerdir. Duygusal bağlllıkta, çalışanlar kurumlarında gönüllük esasıyla yer almaktadır. Örgütün bir parçası olmaktan memnuniyet duymaları esastır.

Devam bağlllı̆̆ı, çalışanın örgütten ayrılmanın getireceği maliyetleri göze alamayarak örgütte zorunluluk hissiyle bağlılık duymasını tanımlamaktadır (Allen ve Meyer, 1990, s. 4). Becker'e (1960) 
Çalışkan, K., \& Ekici, S. (2017). Spor eğitimi veren yükseköğretim kurumlarındaki öğretim elemanlarının örgütsel sinizm algiları ile örgütsel bağlllıklarının araştrilması. Journal of Human Sciences, 14(2), 1674-1689. doi: $10.14687 /$ ihs.v14i2.4485

göre, bireyin iş yerine karşı verdiği emeği ve geliştirdiği yeteneklerini, farklı çalışma ortamlarına aktarmasının zorluğu yatmaktadır.

Normatif bağlllk ise, bireyin örgütte ahlaki açıdan kalmayı doğru bulduğunu ifade etmektedir. Normatif bağlllık, bireyin geçmiş deneyimlerinden ve örgüte dahil oluşlarından sonraki yaşantılarından etkilenmektedir (Allen ve Meyer, 1990).

Derin bir hassasiyet gerektiren konuların başında olan eğitim, modern toplumların öncelik verdiği kamu hizmetlerinden birisidir. Akademik örgütler olan üniversitelerde çalşan öğretim elemanlarının verimlilikleri de, örgütsel bağlllık düzeyleri ve sinizm algıları ile doğrudan ilişkilidir. Ders anlatımları, bilimsel çalısma yürütmeleri, sahip oldukları bilimsel bakış açıları ile kutsal bir değer olan eğitime hizmet eden akademisyenlerin, örgütsel sinizmden uzak olmaları ve bağlılıklarının yüksek düzeyde olması toplumsal fayda açısından bütünüyle gereklilik arz etmektedir. $\mathrm{Bu}$ nedenle, araşturma konusunun seçimi ve yürütülmesinde bu hassasiyet göz önünde bulundurularak hareket edilmiştir. Akademisyenlerin örgütsel sinizm seviyelerinin tespiti ve buna karşın gerekli motivasyon araçları kullanılarak olumsuz düşüncelerden uzaklaştırılmalarının sağlanması, çalışmanın amacı olarak gösterilebilir.

\section{YÖNTEM}

\section{Araştırmanın Modeli}

Spor eğitimi veren yükseköğretim kurumlarındaki öğretim elemanlarının örgütsel sinizm algıları ile örgütsel bağlılıklarının araştırıldığı bu çalısmada, genel tarama yöntemlerinden ilişkisel tarama yöntemi kullanılmıştır.

Tarama modeli geçmişte ya da mevcut dönemde var olan bir durumu manipüle etmeden betimlemeyi hedefleyen araştırma yaklaşımıdır. Onları herhangi bir şekilde değiştirme, etkileme çabası gösterilmez (Karasar, 2009).

\section{Evren ve Örneklem}

Çalışmanın evrenini; Türkiye'de spor eğitimi veren üniversitelerin Spor Bilimleri Fakülteleri, Beden Eğitimi ve Spor Yüksekokulları ve Eğitim Faküllerindeki Beden Eğitimi ve Spor bölümlerinde çalışan 1572 öğretim elemanı oluştururken örneklemini ise bu kurumlarda görevli ve rastgele geri dönüş sistemi ile ankete katllım gösteren 396 öğretim elemanı oluşturmuştur.

\section{Veri Toplama Araçları}

Araştırma grubuna uygulana anket çevrimiçi (online) sistem üzerinde hazırlanmıştır ve 3 bölümden oluşmaktadır. Birinci bölümde katılımcıların cinsiyet, yaş, medeni hal, meslekteki hizmet süresi, kurumdaki hizmet süresi, idari görev ve ünvan gibi demografik bilgilerinin tespit edilmesi amacıyla araştırmacı tarafindan oluşturulan 7 soruluk kişisel bilgi formu yer almaktadır.

İkinci bölümde ‘Örgütsel Sinizm' algisının belirlenmesine yönelik Brandes, Dhalwadkar ve Dean (1999) tarafından geliştirilmiş, Kalağan (2009) tarafından geçerlilik-güvenirliği ve Türkçe’ye uyarlaması yapılmış olan 13 maddelik "Örgütsel Sinizm Ölçeği” kullanılmıştır. Ölçek 5’li Likert tipi bir anket olup; bilişsel, duyuşsal ve davranışsal sinizm olmak üzere üç boyuttan oluşmaktadır. Cronbach alfa iç tutarlılık katsayısı tüm maddeler için $\alpha=0.93$ iken; alt boyutlar için sırasıyla bilişsel $\alpha=0.91$, duyuşsal $\alpha=0.94$ ve davranışsal $\alpha=0.86$ olarak hesaplanmıştır.

Anketin üçüncü ve son bölümünde katılımcıların örgütsel bağlllı düzeylerinin ölçülmesi amaçlanmış ve Allen ve Meyer'in (1996) geliştirdikleri ve Belli (2014) tarafindan Türkçe formunun kullanıldığı 18 maddeden oluşan “Örgütsel Bağlılık Ölçeği”nden yararlanılmıştır. 3, 4, 5 ve 13. maddeleri ters kodlu olan ölçek; duygusal, devam ve normatif olmak üzere 3 alt boyuta sahiptir. Örgütsel bağlllık ölçeğinde Cronbach Alpha değerleri tüm maddeler için $\alpha=0.83$ iken; duygusal bağlllık için $\alpha=0.76$, devam bağllil̆ğ için $\alpha=0.72$ ve normatif bağlllik için $\alpha=0.77$ olarak görülmektedir (Altınöz, Çöp ve Sığındı, 2011, s. 10). 
Çalışkan, K., \& Ekici, S. (2017). Spor eğitimi veren yükseköğretim kurumlarındaki öğretim elemanlarının örgütsel sinizm algiları ile örgütsel bağlllıklarının araştrilması. Journal of Human Sciences, 14(2), 1674-1689. doi: $10.14687 /$ ihs.v14i2.4485

\section{Verilerin Analizi}

İstatistiksel hesaplamalar SPSS (sürüm 20,0) istatistik programında yapılmıştır. Frekans, yüzde ve katılımciların ölçeklerden aldığı puanların ortalamasını belirlemek için betimsel istatistik metodundan yararlanılmıştır. Normallik analizi sonucunda basıklık ve çarpıklık değerlerinin $+1,5$ ile -1,5 arasında olması dikkate alınmış (Tabachnick ve Fidell, 2013) ve verilerin normal dağılım gösterdiği bulgusu ile parametrik testlerin yapılması uygun görülmüştür. Bağımsız iki grup (Cinsiyet, medeni hal, idari görev) arasındaki farkın anlamlı olup olmadığının tespiti için t testi (Independent tTest), ikiden fazla grup için (Yaş, meslekteki hizmet süresi, kurumdaki hizmet süresi, ünvan) Tek Yönlü Varyans Analizi (One Way ANOVA) kullanılmıştır. ANOVA testi sonrası farklılı̆ı̆n hangi gruplar arasında oluştuğunu görmek için ise 'Tukey HSD' testinden faydalanılmıştır. Değişkenler arası ilişkiyi incelemek için Korelasyon (Pearson Correlation) analizi yapılmıştır. Araştırmada tüm bulgular \%95 güven aralığına ve $\mathrm{p}<0.05$ anlamlılık düzeyine göre sınanmıştır.

\section{BULGULAR}

Tablo 1 incelendiğinde; araştırmaya katılan öğretim elemanlarının 291'i (\%73,5) 'Erkek', 105’i (\%26,5) 'Kadın'dır. Yaş değişkeni bakımından 53’ü (\%13,4) '20-29 yaş', 151'i, (\%38,1) '30-39 yaş', 119’u (\%30,1) ‘40-49 yaş’, 73’ü (\%18,4) ‘50 ve üzeri yaş’ aralı̆̆ındadır. Medeni durum açısından bakıldığında da çoğunlukla (\%72,7) 'Evli' oldukları görülmektedir. Akademisyenlerin meslekteki hizmet sürelerine bakıldığında 111'i (\%28,0) '1-5 y1l', 31'i (\%7,8) '6-10 yll', 66's1 (\%16,7) '11 - 15 yll', 79'u (\%19,9) '16-20 yll', 109'u (\%27,5) '21 ve üzeri' yıldır meslek içerisinde oldukları görülmektedir. Bu katılımcıların, araştırmaya katıldıkları anda bağlı bulunduğu kurumlarında geçirdikleri süreler incelendiğinde ise yarıya yakını $169(\% 42,7)$ henüz 5 yılı doldurmamıştır. Ayrıca katılımcıların yaklaşık üçte ikisi $(\% 61,4)$ idari bir görevde yer almamaktadır. Ünvan açısından değerlendirildiğinde öğretim elemanlarının yarıdan fazlasının $(\% 55,0)$ öğretim üyeliği pozisyonuna yükseldiği görülür iken 'Uzman' kadrosu $(\% 0,8)$ tespit edilen en seyrek pozisyondur.

Tablo 1. Araștırmaya Katılan Ögrretim Elemanlarna Ait Demografik Özellikler

\begin{tabular}{lcc|lcc}
\hline Cinsiyet & f & $\mathbf{9}$ & Kurumdaki Hizmet Süresi & f & $\mathbf{\%}$ \\
Erkek & 291 & 73,5 & $1-5$ yll & 169 & 42,7 \\
Kadın & 105 & 26,5 & $6-10$ yll & 52 & 13,1 \\
Yaş & & & $11-15$ yll & 55 & 13,9 \\
$20-29$ & 53 & 13,4 & $16-20$ yll & 60 & 15,2 \\
$30-39$ & 151 & 38,1 & 21 ve üzeri & 60 & 15,1 \\
$40-49$ & 119 & 30,1 & İdari Görev & & \\
50 ve üzeri & 73 & 18,4 & Evet & 153 & 38,6 \\
Medeni Durum & & & Hayır & 243 & 61,4 \\
Bekâr & 108 & 27,3 & Ünvan & & \\
Evli & 288 & 72,7 & Uzman & 3 & 0,8 \\
Meslekteki Hizmet Süresi & & & Okutman & 29 & 7,3 \\
$1-5$ yll & 111 & 28,0 & Araştırma Görevlisi & 87 & 22 \\
$6-10$ yll & 31 & 7,8 & Ögretim Görevlisi & 59 & 14,9 \\
$11-15$ yll & 66 & 16,7 & Yardımc1 Doçent & 130 & 32,8 \\
$16-20$ yll & 79 & 19,9 & Doçent & 74 & 18,7 \\
21 ve üzeri & 109 & 27,6 & Profesör & 14 & 3,5 \\
\hline
\end{tabular}

Tablo 2'de, araştırmaya katılan akademik personelin örgütsel sinizm ortalamasının ' $\bar{X}$ =2,54' yani 'Düşük' düzeyde, örgütsel bağlllıklarının ise ' $\bar{X}=3,30$ ' yani 'Orta' düzeyde olduğu görülmektedir. 
Çalışkan, K., \& Ekici, S. (2017). Spor eğitimi veren yükseköğretim kurumlarındaki öğretim elemanlarının örgütsel sinizm algıları ile örgütsel bağlılıklarının araştırlması. Journal of Human Sciences, 14(2), 1674-1689. doi: $10.14687 /$ ihs.v14i2.4485

Tablo 2. Ölçeklere Ait Ortalamalar

\begin{tabular}{lcc|lcc}
\hline Boyutlar & $\bar{X}$ & $\mathbf{s}$ & Boyutlar & $\bar{X}$ & $\mathbf{s}$ \\
\hline Örgütsel Sinizm & 2,54 & 0,924 & Örgütsel Bağlllık & 3,30 & 0,623 \\
1. Bilişsel Sinizm & 2,84 & 1,096 & 1. Duygusal Bağlllık & 3,61 & 0,991 \\
2. Duyuşsal Sinizm & 2,17 & 1,175 & 2. Devam Bağlllı̆̆1 & 3,22 & 0,761 \\
3. Davranıssal Sinizm & 2,55 & 0,968 & 3. Normatif Bağlllık & 3,08 & 0,773 \\
\hline
\end{tabular}

Tablo 3’te, öğretim elemanlarının kurumdaki hizmet süresi değişkenine göre duyuşsal sinizm boyutunda istatistiksel olarak farklılıklar tespit edilmiştir. Farklılıkların hangi gruptan kaynaklandığını görmek için Tukey testi uygulanmıştır. Test sonucunda, çalışma süresi 1-5 yll ile 6-10 yll arasında farklılık oluştuğu ve çalışma süresi 1-5 y1l olanların örgütsel sinizmlerinin daha düşük olduğu görülmüştür.

Tablo 3. Kurumdaki Hįmet Süresi Değişkenine Göre Ögretim Elemanlarmm Örgütsel Siniz̨m ve Alt Boyutlarna İliskin ANOVA Testi Sonuclar

\begin{tabular}{|c|c|c|c|c|c|c|c|c|}
\hline Boyutlar & Sira & $\begin{array}{l}\text { Kurumdaki } \\
\text { Hizmet Süresi }\end{array}$ & $\mathbf{n}$ & $\bar{X}$ & $\mathbf{s}$ & $\mathbf{F}$ & $\mathrm{p}$ & $\begin{array}{c}\text { Fark } \\
\text { (Tukey } \\
\text { ) }\end{array}$ \\
\hline \multirow{5}{*}{ Örgütsel Sinizm } & 1 & $1-5$ & 169 & 2,45 & 0,93 & \multirow{5}{*}{1,111} & \multirow{5}{*}{,351 } & \multirow{5}{*}{-} \\
\hline & 2 & $6-10$ & 52 & 2,75 & 1,05 & & & \\
\hline & 3 & $11-15$ & 55 & 2,60 & 0,94 & & & \\
\hline & 4 & $16-20$ & 60 & 2,57 & 0,94 & & & \\
\hline & 5 & 21 ve üzeri & 60 & 2,58 & 0,75 & & & \\
\hline \multirow{5}{*}{$\begin{array}{l}\text { Davranışsal } \\
\text { Sinizm }\end{array}$} & 1 & $1-5$ & 169 & 2,60 & 1,00 & \multirow{5}{*}{0,345} & \multirow{5}{*}{847} & \multirow{5}{*}{-} \\
\hline & 2 & $6-10$ & 52 & 2,61 & 0,99 & & & \\
\hline & 3 & $11-15$ & 55 & 2,54 & 0,99 & & & \\
\hline & 4 & $16-20$ & 60 & 2,44 & 1,04 & & & \\
\hline & 5 & 21 ve üzeri & 60 & 2,53 & 0,76 & & & \\
\hline \multirow{5}{*}{ Bilişsel Sinizm } & 1 & $1-5$ & 169 & 2,72 & 1,09 & \multirow{5}{*}{1,196} & \multirow{5}{*}{, 320} & \multirow{5}{*}{-} \\
\hline & 2 & $6-10$ & 52 & 3,06 & 1,26 & & & \\
\hline & 3 & $11-15$ & 55 & 2,94 & 1,10 & & & \\
\hline & 4 & $16-20$ & 60 & 2,85 & 1,10 & & & \\
\hline & 5 & 21 ve üzeri & 60 & 2,90 & 0,92 & & & \\
\hline \multirow{5}{*}{ Duyuşsal Sinizm } & 1 & $1-5$ & 169 & 1,97 & 1,12 & \multirow{5}{*}{2,628} & \multirow{5}{*}{,042 } & \multirow{5}{*}{$1-2$} \\
\hline & 2 & $6-10$ & 52 & 2,50 & 1,29 & & & \\
\hline & 3 & $11-15$ & 55 & 2,23 & 1,25 & & & \\
\hline & 4 & $16-20$ & 60 & 2,35 & 1,25 & & & \\
\hline & 5 & 21 ve üzeri & 60 & 2,22 & 0,99 & & & \\
\hline
\end{tabular}

Tablo 4'te, öğretim elemanlarının idari görevlerinin olup olmamasının örgütsel sinizm algılarında farklılık yaratıp yaratmadığını gösteren bulgular yer almaktadır. İlgili tabloda sinizmin ortalamasinda [ $\mathrm{t}=-3,454, \mathrm{p}=, 001]$, bilişsel boyutta $[\mathrm{t}=-4,464, \mathrm{p}=, 000]$ ve duyuşsal boyutta $[\mathrm{t}=-2,782$, $\mathrm{p}=, 006]$ idari görev değişkeni bakımından istatistiksel olarak anlamlı farklılıklar görülmektedir. Farklılıkların tespit edildiği noktaların ortalamalarına bakıldı̆̆ında, idari görevi bulunmayan öğretim elemanlarının sinizm algılarının daha yüksek olduğu görülmüștür. 
Çalışkan, K., \& Ekici, S. (2017). Spor eğitimi veren yükseköğretim kurumlarındaki öğretim elemanlarının örgütsel sinizm algıları ile örgütsel bağlılıklarının araştırılması. Journal of Human Sciences, 14(2), 1674-1689. doi:10.14687/jhs.v14i2.4485

Tablo 4. İdari Görev Değişkenine Göre Ögretim Elemanlarnm Örgütsel Sinižm ve Alt Boyutlarna Iliş̧kin t Testi Sonuclar

\begin{tabular}{|c|c|c|c|c|c|c|}
\hline Boyutlar & İdari Görev & $\mathbf{n}$ & $\bar{X}$ & $\mathbf{s}$ & $\mathbf{t}$ & $\mathrm{p}$ \\
\hline \multirow{2}{*}{ Örgütsel Sinizm } & Evet & 153 & 2,35 & 0,86 & \multirow{2}{*}{$-3,454$} & \multirow{2}{*}{,001 } \\
\hline & Hayır & 243 & 2,67 & 0,94 & & \\
\hline \multirow{2}{*}{ Bilişsel } & Evet & 153 & 2,54 & 1,01 & \multirow{2}{*}{$-4,464$} & \multirow{2}{*}{,000 } \\
\hline & Haylr & 243 & 3,03 & 1,11 & & \\
\hline \multirow{2}{*}{ Duyuşsal } & Evet & 153 & 1,97 & 1,06 & \multirow{2}{*}{$-2,782$} & \multirow{2}{*}{,006 } \\
\hline & Haylr & 243 & 2,30 & 1,23 & & \\
\hline \multirow{2}{*}{ Davranışsal } & Evet & 153 & 2,49 & 0,95 & \multirow{2}{*}{$-1,170$} & \multirow{2}{*}{,243 } \\
\hline & Hayır & 243 & 2,60 & 0,98 & & \\
\hline
\end{tabular}

Tablo 5’te ünvan değişkenine göre, öğretim elemanlarının örgütsel sinizmin davranışsal alt boyutunda $(\mathrm{F}=3,395 ; \mathrm{p}=, 003)$ istatistiksel olarak anlamlı farklllıklar tespit edilmiştir. Farklllıkların hangi gruplar arasında oluştuğunu belirlemek için Tukey HSD testi uygulanmıştır. Test sonucunda farklılığın okutmanlar ile araştırma görevlileri ve doçentler arasında oluştuğu görülmektedir. Bu üç grup arasında ise 'Okutman'ların davranışsal sinizm algıları $(\bar{X}=2,12)$ en düşük düzeydedir.

Tablo 5. Ünvan Değiskeenine Göre Öğretim Elemanlarnm Örö̈tsel Sinižm ve Alt Boyutlarna Ilişkin ANOVA Testi Sonuclar

\begin{tabular}{|c|c|c|c|c|c|c|c|c|}
\hline Boyutlar & Sira & Ünvan & $\mathbf{n}$ & $\overline{\bar{X}}$ & $\mathrm{~s}$ & F & $\mathrm{p}$ & Fark (Tukey) \\
\hline \multirow{7}{*}{ Örgütsel Sinizm } & 1 & Uzman & 3 & 2,44 & 0,36 & \multirow{7}{*}{1,155} & \multirow{7}{*}{,330 } & \multirow{7}{*}{-} \\
\hline & 2 & Okutman & 29 & 2,19 & 0,73 & & & \\
\hline & 3 & Araştırma Görevlisi & 87 & 2,59 & 0,97 & & & \\
\hline & 4 & Öğretim Görevlisi & 59 & 2,49 & 0,98 & & & \\
\hline & 5 & Yardımcı Doçent & 130 & 2,59 & 0,97 & & & \\
\hline & 6 & Doçent & 74 & 2,65 & 0,83 & & & \\
\hline & 7 & Profesör & 14 & 2,33 & 0,74 & & & \\
\hline \multirow{7}{*}{ Bilişsel Sinizm } & 1 & Uzman & 3 & 2,93 & 1,10 & \multirow{7}{*}{0,324} & \multirow{7}{*}{,925 } & \multirow{7}{*}{-} \\
\hline & 2 & Okutman & 29 & 2,68 & 0,97 & & & \\
\hline & 3 & Araştırma Görevlisi & 87 & 2,77 & 1,14 & & & \\
\hline & 4 & Öğretim Görevlisi & 59 & 2,91 & 1,19 & & & \\
\hline & 5 & Yardımcı Doçent & 130 & 2,91 & 1,14 & & & \\
\hline & 6 & Doçent & 74 & 2,83 & 0,97 & & & \\
\hline & 7 & Profesör & 14 & 2,71 & 1,10 & & & \\
\hline \multirow{7}{*}{ Davranışsal Sinizm } & 1 & Uzman & 3 & 2,75 & 1,09 & \multirow{7}{*}{3,395} & \multirow{7}{*}{,003 } & \multirow{7}{*}{$\begin{array}{l}2-3 \\
2-6\end{array}$} \\
\hline & 2 & Okutman & 29 & 2,12 & 0,72 & & & \\
\hline & 3 & Araştırma Görevlisi & 87 & 2,78 & 0,99 & & & \\
\hline & 4 & Öğretim Görevlisi & 59 & 2,34 & 0,93 & & & \\
\hline & 5 & Yardımc1 Doçent & 130 & 2,51 & 0,99 & & & \\
\hline & 6 & Doçent & 74 & 2,78 & 0,98 & & & \\
\hline & 7 & Profesör & 14 & 2,21 & 0,67 & & & \\
\hline \multirow{7}{*}{ Duyuşsal Sinizm } & 1 & Uzman & 3 & 1,50 & 0,50 & \multirow{7}{*}{1,571} & \multirow{7}{*}{,053 } & \multirow{7}{*}{ - } \\
\hline & 2 & Okutman & 29 & 1,64 & 0,87 & & & \\
\hline & 3 & Araştırma Görevlisi & 87 & 2,17 & 1,25 & & & \\
\hline & 4 & Öğretim Görevlisi & 59 & 2,13 & 1,23 & & & \\
\hline & 5 & Yardımcı Doçent & 130 & 2,28 & 1,21 & & & \\
\hline & 6 & Doçent & 74 & 2,29 & 1,12 & & & \\
\hline & 7 & Profesör & 14 & 1,96 & 0,83 & & & \\
\hline
\end{tabular}


Çalışkan, K., \& Ekici, S. (2017). Spor eğitimi veren yükseköğretim kurumlarındaki öğretim elemanlarının örgütsel sinizm algıları ile örgütsel bağlılıklarının araştırlması. Journal of Human Sciences, 14(2), 1674-1689. doi: $10.14687 /$ ihs.v14i2.4485

Öğretim elemanlarının cinsiyet, yaş, medeni durum ve meslekteki hizmet süresi değişkenlerine göre örgütsel sinizm algiları arasında istatistiksel olarak anlamlı farklilıklara rastlanmamıştır.

Tablo 6'da, öğretim elemanlarının cinsiyet değişkenine göre duygusal bağlllık düzeyleri $[\mathrm{t}=2,888, \mathrm{p}=, 004]$ ve devam bağlllk düzeylerinde [ $\mathrm{t}=-2,046, \mathrm{p}=, 041]$ istatistiksel olarak anlamlı farklılıklar tespit edilmiştir. Farklllklar incelendiğinde; duygusal boyutta erkek öğretim elemanlarının, kadın öğretim elemanlarına oranla aritmetik ortalamalarının $(\bar{X}=3,71)$ daha yüksek olduğu görülmektedir. Devam bağlllı̆̆ı boyutunda ise 'Kadın'ların aritmetik ortalamaları $(\bar{X}=3,35)$ erkeklere oranla daha yüksek çıkmıştır.

Tablo 6. Cinsiyet Değgiskenine Göre Öğretim Elemanlarmm Örgütsel Bă̆lllk ve Alt Boyutlarnna İlişkin t Testi Sonuclar

\begin{tabular}{|c|c|c|c|c|c|c|}
\hline Boyutlar & Cinsiyet & $\mathbf{n}$ & $\bar{X}$ & s & $\mathbf{t}$ & $\mathrm{p}$ \\
\hline \multirow{2}{*}{ Örgütsel Bağlılık } & Erkek & 291 & 3,33 & 0,62 & \multirow{2}{*}{1,349} & \multirow{2}{*}{,178 } \\
\hline & Kadın & 105 & 3,24 & 0,62 & & \\
\hline \multirow{2}{*}{ Duygusal Bağlllık } & Erkek & 291 & 3,71 & 0,92 & \multirow{2}{*}{2,888} & \multirow{2}{*}{,004 } \\
\hline & Kadin & 105 & 3,36 & 1,13 & & \\
\hline \multirow{2}{*}{ Devam Bağlllı̆̆1 } & Erkek & 291 & 3,17 & 0,75 & \multirow{2}{*}{$-2,046$} & \multirow{2}{*}{,041 } \\
\hline & Kadın & 105 & 3,35 & 0,78 & & \\
\hline \multirow{2}{*}{ Normatif Bağlllık } & Erkek & 291 & 3,11 & 0,77 & \multirow{2}{*}{1,240} & \multirow{2}{*}{,216 } \\
\hline & Kadın & 105 & 3,00 & 0,77 & & \\
\hline
\end{tabular}

Tablo 7'de görüleceği şekilde, öğretim elemanlarının yaş değişkenine göre, devam bağlllı̆̆1 boyutunda $(\mathrm{F}=4,262 ; \mathrm{p}=, 006)$ istatistiksel olarak anlamlı farklılık bulunmaktadır. Farklılığın hangi gruplar arasında oluştuğunu belirlemek üzere Post Hoc testlerinden, varyansların homojenliği ilkesine uygun olarak Tukey HSD testine başvurulmuştur. Test sonucunda gruplar arası farkın '2029 yaş' ile '30-39 yaş’ ve '20-29 yaş' ile '50 ve üzeri' arasında oluştuğu görülmektedir. Bu üç grup arasında ise 20-29 yaş aralığında olan öğretim elemanlarının devam bağlllı̆̆1 $(\bar{X}=3,52)$ digger iki gruba göre yüksek düzeydedir.

Tablo 7. Yas Değ̈skenine Göre Ögretim Elemanlarmin Örgütsel Bağhllkeve Alt Bovutlarna İliskin Anova Testi Sonuclarn

\begin{tabular}{|c|c|c|c|c|c|c|c|c|}
\hline & Sira & Yaş & $\mathrm{n}$ & $\overline{\bar{X}}$ & $\mathbf{s}$ & $\mathbf{F}$ & $\mathrm{p}$ & Anlamlı Fark \\
\hline \multirow{4}{*}{ Örgütsel Bağl1lık } & 1 & $20-29$ & 53 & 3,38 & 0,57 & \multirow{4}{*}{1,577} & \multirow{4}{*}{,194 } & \multirow{4}{*}{ - } \\
\hline & 2 & $30-39$ & 151 & 3,25 & 0,63 & & & \\
\hline & 3 & $40-49$ & 119 & 3,39 & 0,63 & & & \\
\hline & 4 & 50 ve üzeri & 73 & 3,25 & 0,62 & & & \\
\hline \multirow{4}{*}{ Duygusal Bağlilık } & 1 & $20-29$ & 53 & 3,52 & 1,02 & \multirow{4}{*}{1,168} & \multirow{4}{*}{,322 } & \multirow{4}{*}{ - } \\
\hline & 2 & $30-39$ & 151 & 3,54 & 1,01 & & & \\
\hline & 3 & $40-49$ & 119 & 3,75 & 1,00 & & & \\
\hline & 4 & 50 ve üzeri & 73 & 3,65 & 0,90 & & & \\
\hline \multirow{4}{*}{ Devam Bağllliğ1 } & 1 & $20-29$ & 53 & 3,52 & 0,68 & \multirow{4}{*}{4,262} & \multirow{4}{*}{,006 } & \multirow{4}{*}{$\begin{array}{l}1-2 \\
1-4\end{array}$} \\
\hline & 2 & $30-39$ & 151 & 3,15 & 0,78 & & & \\
\hline & 3 & $40-49$ & 119 & 3,27 & 0,78 & & & \\
\hline & 4 & 50 ve üzeri & 73 & 3,07 & 0,69 & & & \\
\hline \multirow{4}{*}{ Normatif Bağlllik } & 1 & $20-29$ & 53 & 3,12 & 0,71 & \multirow{4}{*}{0,492} & \multirow{4}{*}{ 688 } & \multirow{4}{*}{ - } \\
\hline & 2 & $30-39$ & 151 & 3,06 & 0,75 & & & \\
\hline & 3 & $40-49$ & 119 & 3,14 & 0,85 & & & \\
\hline & 4 & 50 ve üzeri & 73 & 3,02 & 0,75 & & & \\
\hline
\end{tabular}


Çalışkan, K., \& Ekici, S. (2017). Spor eğitimi veren yükseköğretim kurumlarındaki öğretim elemanlarının örgütsel sinizm algiları ile örgütsel bağlllıklarının araştrilması. Journal of Human Sciences, 14(2), 1674-1689. doi:10.14687/jhs.v14i2.4485

Tablo 8 incelendiğinde, öğretim elemanlarının meslekteki hizmet süreleri değişkenine göre devam bağlllı̆g alt boyutunda $(F=5,293 ; p=, 000)$ istatistiksel olarak anlamlı bir farklıllk tespit edilmiştir. Farklıllğın hangi gruplar arasında oluştuğunu tespit etmek amaciyla yapilan 'Tukey HSD' testi sonucuna göre; gruplar arası farkın '6-10 yil' ile '1-5 y1l' ve '6-10 y1l' ile '16-20 yil' arasinda oluştuğu görülmektedir. Bu üç grup arasında ise ‘1 $1-5$ yll’ $(\bar{X}=3,37)$, öğretim elemanlarının devam bağlılığının meslekteki hizmet sürelerine göre en yüksek görüldügü yıl aralığı olmuştur.

Tablo 8. Meslekteki Hizmet Süresi Değişkenine Göre Ögrretim Elemanlarmin Örgütsel Bağhllhk ve Alt Boyutlarna İliskin Anova Testi Sonuclarn

\begin{tabular}{|c|c|c|c|c|c|c|c|}
\hline & Meslekteki Hizmet Süresi & $\mathbf{n}$ & $\bar{X}$ & $\mathbf{s}$ & $\mathbf{F}$ & $\mathrm{p}$ & Anlamli Fark \\
\hline \multirow{5}{*}{ Örgütsel Bağlllık } & $1-5$ & 111 & 3,36 & 0,62 & \multirow{5}{*}{1,402} & \multirow{5}{*}{,233 } & \multirow{5}{*}{-} \\
\hline & $6-10$ & 31 & 3,14 & 0,65 & & & \\
\hline & $11-15$ & 66 & 3,29 & 0,65 & & & \\
\hline & $16-20$ & 79 & 3,40 & 0,63 & & & \\
\hline & 21 ve üzeri & 109 & 3,25 & 0,59 & & & \\
\hline \multirow{5}{*}{ Duygusal Bağlllık } & $1-5$ & 111 & 3,31 & 1,00 & \multirow{5}{*}{0,494} & \multirow{5}{*}{, 740} & \multirow{5}{*}{-} \\
\hline & $6-10$ & 31 & 3,59 & 1,07 & & & \\
\hline & $11-15$ & 66 & 3,70 & 1,12 & & & \\
\hline & $16-20$ & 79 & 3,49 & 0,96 & & & \\
\hline & 21 ve üzeri & 109 & 3,68 & 0,91 & & & \\
\hline \multirow{5}{*}{ Devam Bağll1ı̆̆1 } & $1-5$ & 111 & 3,37 & 0,76 & \multirow{5}{*}{5,293} & \multirow{5}{*}{, 000} & \multirow{5}{*}{$\begin{array}{l}2-1 \\
2-4\end{array}$} \\
\hline & $6-10$ & 31 & 2,77 & 0,87 & & & \\
\hline & $11-15$ & 66 & 3,21 & 0,74 & & & \\
\hline & $16-20$ & 79 & 3,36 & 0,71 & & & \\
\hline & 21 ve üzeri & 109 & 3,10 & 0,72 & & & \\
\hline \multirow{5}{*}{ Normatif Bağlllık } & $1-5$ & 111 & 3,11 & 0,81 & \multirow{5}{*}{1,055} & \multirow{5}{*}{,378 } & \multirow{5}{*}{-} \\
\hline & $6-10$ & 31 & 2,95 & 0,78 & & & \\
\hline & $11-15$ & 66 & 3,17 & 0,83 & & & \\
\hline & $16-20$ & 79 & 3,15 & 0,72 & & & \\
\hline & 21 ve üzeri & 109 & 2,99 & 0,74 & & & \\
\hline
\end{tabular}

Tablo 9'da öğretim elemanlarının idari görevlerinin olup olmamasının örgütsel bağlllık hislerinde farklılık yaratıp yaratmadığ1 ile ilgili t testi sonuçları yer almaktadır. Devam bağlllı̆̆1 boyutunda anlamlı bir fark gözlenmezken, örgütsel bağlılığın genelinde $[\mathrm{t}=2,439, \mathrm{p}=, 015]$, duygusal bağlllıkta [ $\mathrm{t}=3,116, \mathrm{p}=, 002]$ ve normatif bağllik boyutunda $[\mathrm{t}=2,066, \mathrm{p}=, 040]$ istatistiksel olarak anlamlı farklılıklar tespit edilmiştir. Farkll11kların tespit edildiği tüm noktalarda ortalamalara bakıldığında, idari görevi bulunan öğretim elemanlarının, idari görevi olmayan personele oranla daha yüksek bağlılık hissine sahip oldukları görülmektedir. 
Çalışkan, K., \& Ekici, S. (2017). Spor eğitimi veren yükseköğretim kurumlarındaki öğretim elemanlarının örgütsel sinizm algiları ile örgütsel bağlllıklarının araştrilması. Journal of Human Sciences, 14(2), 1674-1689. doi:10.14687/jhs.v14i2.4485

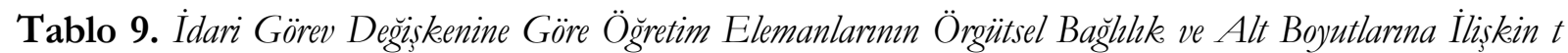
Testi Sonuclar

\begin{tabular}{|c|c|c|c|c|c|c|}
\hline Boyutlar & İdari Görev & $\mathbf{n}$ & $\bar{X}$ & $\mathbf{s}$ & $\mathbf{t}$ & $\mathrm{p}$ \\
\hline \multirow{2}{*}{ Örgütsel Bağl1lık } & Evet & 153 & 3,40 & 0,62 & \multirow{2}{*}{2,439} & \multirow{2}{*}{,015 } \\
\hline & Hayır & 243 & 3,25 & 0,62 & & \\
\hline \multirow{2}{*}{ Duygusal Bağlılık } & Evet & 153 & 3,81 & 0,90 & \multirow{2}{*}{3,116} & \multirow{2}{*}{, 002} \\
\hline & Hayır & 243 & 3,50 & 1,03 & & \\
\hline \multirow{2}{*}{ Devam Bağlllı̆g1 } & Evet & 153 & 3,21 & 0,77 & \multirow{2}{*}{$-0,154$} & \multirow{2}{*}{877} \\
\hline & Hayır & 243 & 3,23 & 0,76 & & \\
\hline \multirow{2}{*}{ Normatif Bağlll1k } & Evet & 153 & 3,18 & 0,77 & \multirow{2}{*}{2,066} & \multirow{2}{*}{040} \\
\hline & Hayır & 243 & 3,02 & 0,77 & & \\
\hline
\end{tabular}

Tablo 10’da öğretim elemanlarının ünvan değişkenine göre devam bağlllı̆̆1 alt boyutunda $(\mathrm{F}=5,872 ; \mathrm{p}=, 000)$ istatistiksel olarak anlamlı farklılıklar tespit edilmiştir. Yapılan 'Tukey HSD' testi sonucunda farklıllğın araştırma görevlileri ile yardımcı doçent, doçent ve profesör'ler arasında oluştuğu görülmektedir. Bu dört grup arasında ise 'Araştırma Görevlileri'nin devam bağlllı̆̆1 seviyeleri $(\bar{X}=3,55)$ diğer üç gruba göre en yüksek düzeydedir.

Tablo 10. Ünvan Değģskenine Göre Öğretim Elemanlarnm Örgütsel Bağhllk. ve Alt Boyutlarna İlişkin Anova Testi Sonuclar

\begin{tabular}{|c|c|c|c|c|c|c|c|c|}
\hline Boyutlar & Sira & Ünvan & $\mathrm{n}$ & $\overline{\bar{X}}$ & $\mathrm{~s}$ & $\mathbf{F}$ & $\mathrm{p}$ & Fark (Tukey) \\
\hline \multirow{7}{*}{ Örgütsel Bağlllık } & 1 & Uzman & 3 & 3,19 & 0,42 & \multirow{7}{*}{2,044} & \multirow{7}{*}{059} & \multirow{7}{*}{ - } \\
\hline & 2 & Okutman & 29 & 3,47 & 0,56 & & & \\
\hline & 3 & Arastırma Görevlisi & 87 & 3,40 & 0,61 & & & \\
\hline & 4 & Öğretim Görevlisi & 59 & 3,37 & 0,55 & & & \\
\hline & 5 & Yardımc1 Doçent & 130 & 3,17 & 0,66 & & & \\
\hline & 6 & Doçent & 74 & 3,36 & 0,62 & & & \\
\hline & 7 & Profesör & 14 & 3,15 & 0,67 & & & \\
\hline \multirow[t]{7}{*}{ Duygusal Bağllitk } & 1 & Uzman & 3 & 3,50 & 0,17 & \multirow{7}{*}{1,029} & \multirow{7}{*}{, 406 } & \multirow{7}{*}{ - } \\
\hline & 2 & Okutman & 29 & 3,84 & 0,77 & & & \\
\hline & 3 & Araştırma Görevlisi & 87 & 3,50 & 1,04 & & & \\
\hline & 4 & Öğretim Görevlisi & 59 & 3,71 & 1,01 & & & \\
\hline & 5 & Yardımcı Doçent & 130 & 3,52 & 1,03 & & & \\
\hline & 6 & Doçent & 74 & 3,76 & 0,93 & & & \\
\hline & 7 & Profesör & 14 & 3,69 & 0,98 & & & \\
\hline \multirow[t]{7}{*}{ Devam Bağlllı̆̆1 } & 1 & Uzman & 3 & 2,72 & 0,75 & \multirow{7}{*}{5,872} & \multirow{7}{*}{, 000} & \multirow{7}{*}{$\begin{array}{l}3-5 \\
3-6 \\
3-7\end{array}$} \\
\hline & 2 & Okutman & 29 & 3,39 & 0,63 & & & \\
\hline & 3 & Araştırma Görevlisi & 87 & 3,55 & 0,69 & & & \\
\hline & 4 & Öğretim Görevlisi & 59 & 3,28 & 0,72 & & & \\
\hline & 5 & Yardımcı Doçent & 130 & 3,00 & 0,77 & & & \\
\hline & 6 & Doçent & 74 & 3,17 & 0,75 & & & \\
\hline & 7 & Profesör & 14 & 2,92 & 0,76 & & & \\
\hline \multirow[t]{7}{*}{ Normatif Bağlll1k } & 1 & Uzman & 3 & 3,33 & 0,60 & \multirow{7}{*}{0,841} & \multirow{7}{*}{, 539} & \multirow{7}{*}{-} \\
\hline & 2 & Okutman & 29 & 3,18 & 0,72 & & & \\
\hline & 3 & Araștırma Görevlisi & 87 & 3,16 & 0,79 & & & \\
\hline & 4 & Öğretim Görevlisi & 59 & 3,11 & 0,72 & & & \\
\hline & 5 & Yardımc1 Doçent & 130 & 2,99 & 0,78 & & & \\
\hline & 6 & Docent & 74 & 3,13 & 0,81 & & & \\
\hline & 7 & Profesör & 14 & 2,85 & 0,74 & & & \\
\hline
\end{tabular}


Çalışkan, K., \& Ekici, S. (2017). Spor eğitimi veren yükseköğretim kurumlarındaki öğretim elemanlarının örgütsel sinizm algiları ile örgütsel bağlllıklarının araştrilması. Journal of Human Sciences, 14(2), 1674-1689. doi:10.14687/jhs.v14i2.4485

Öğretim elemanlanının medeni durum ve kurumdaki hizmet süresi değişkenlerine göre örgütsel bağllikk seviyelerinde, istatistiksel olarak anlamlı farklılıklara rastlanmamıştır.

Tablo 11 incelendiğinde, örgütsel sinizm ile örgütsel bağlllik arasinda $(\mathrm{r}=-0,467 ; \mathrm{P}<0,01)$ istatistiksel olarak orta düzeyde negatif yönlü bir ilişki söz konusudur.

Tablo 11. Örgütsel Sinizm ile Örgütsel Bağhlhk. Arasındaki İlişki (Pearson Korelasyon Testi)

\begin{tabular}{c|c}
\hline & Örgütsel Bağlllık \\
\hline Örgütsel Sinizm &,$- 467^{* *}$ \\
Sig. (2-tailed) & $\mathrm{p}=, 000$ \\
\hline
\end{tabular}

\section{TARTIŞMA VE SONUÇ}

Araşturma evrenini oluşturan toplam 1572 öğretim elemanının 396's1 çalışmaya katulım göstermiştir. Katılımcıların 291'i erkek, 105’i kadındır. 30 - 50 yaş aralığ1 \%68,1 ile büyük çoğunluğu oluşturmaktadır. Kattlımcıların \%73,7'si evliyken, \%42,7'si mevcut halde bulundukları kurumlarında henüz 5 yllını tamamlamamış olanlardır. İdari görevi bulunan akademik personel yaklaşık $(\% 61,4)$ üçte iki oranındadır. Yardımcı doçentler $\% 32,8$ 'lik oranla çalısmaya katılım gösteren en büyük grubu oluşturmuşlardır.

Katılımcıların örgütsel sinizm ortalamasının düşük düzeyde, örgütsel bağlılıklarının ise orta düzeyde olduğu görülmüştür. Sinizmin düşük olduğunu gösteren bu sonuç, kamu ve özel hastanelerde çalışan sağlık personellerinin sinizm düzeylerinin araştırıldığı Üreten'in (2016) çalışmasında ve Uzun ve Ayık'in (2016) okul müdürleri ile öğretmenleri kapsayan araştırma sonuçlarını desteklemektedir.

Araştırmaya katılan öğretim elemanlarının örgütsel sinizm gösterme eğilimleri cinsiyet, yaş, medeni durum ve meslekteki hizmet süresi değişkenlerine göre anlamlı düzeyde farklılık göstermemektedir. Literatürde örgütsel sinizmin cinsiyet değişkenine göre farkllık yaratmadığının tespit edildiği benzer bulgulara alanyazında; Karademir (2016) ile Balay, Kaya ve Cülha'nın (2013) öğretmenler üzerine yaptı̆̆ı çalışmasında, Yavuz ve Bedük’ün (2016) banka çalışanlarını kapsayan araştırmalarında, Kalağan (2009) tarafından yürütülen araştırma görevlilerinin sinizm tutumları arasındaki ilişkiyi incelediği çalısmasında ve Efilti, Gönen ve Öztürk’ün (2008) otel çalışanları üzerine yaptıkları araştırmalarında rastlamak mümkündür.

Yaş değişkeni açısından ise benzer bulgular Akyüz ve Yurduseven'in (2015) sağllk çalışanlarını kapsayan araştırması ile örtüşmektedir. Balıkçıŏlu'nun (2013) çalışması ile ise paralellik göstermemektedir. Balıkçıŏlu'nun çalışmasında, çalışanların yaşları arttıkça sinizmlerinin azaldığ1 görülmektedir. $\mathrm{Bu}$ sonuç, turizm sektöründe ilerleyen yaşlardaki çalışanların iş kaygılarının azabileceği öngörüsü ile açılanabilir. Akademide ise yaşın ilerlemesi beraberinde genellikle ünvan açısından yükselmeyi de getirmesi, kurum içi çekişmelerin sinizme yol açabilmesini mümkün k1labilmektedir.

Kurumdaki hizmet süresine gore, duyuşsal sinizm alt boyutunda; 1-5 yıl arası çalışma süresi olanlar ile 6-10 yıl arası çalışma süresi olanlar arasında istatistiksel olarak farklılığın oluştuğu tespit edilmiştir. 6-10 yıl çalışma süresi olanların duyuşsal sinizm düzeyi daha yüksek çıkmıştır. Çalışma süresi arttıkça sinizm düzeyinin arttı̆̆ sonucu, uzun süreler kurumlarında bulunan çalsşanların giderek negatif olayların etkisinde kaldığı ve bu olumsuzlukları duygusal anlamda hissetmeye başladıkları şeklinde açıklanabilir.

Kurumlarında idari görevi olmayanların davranışsal sinizm alt boyutu haricinde tüm boyutlarda daha yüksek düzeyde sinizm yaşadıkları gözlemlenmiştir. Bu durumun yönetim kademesinde bulunan personelin emri altındaki çalışanlara uygulayabileceği baskıyla ilişkili olabileceği düşünülebilir. 
Çalışkan, K., \& Ekici, S. (2017). Spor eğitimi veren yükseköğretim kurumlarındaki öğretim elemanlarının örgütsel sinizm algiları ile örgütsel bağlllıklarının araştrilması. Journal of Human Sciences, 14(2), 1674-1689. doi:10.14687/jhs.v14i2.4485

Öğretim elemanlarının ünvan değişkeni açısından davranışsal sinizm alt boyutunda en düşük sinizm hissi olanlar okutmanlar iken, en yüksek düzeyde sinizm yaşayan gruplar aynı aritmetik ortalama ile araştırma görevlileri ve doçentler çıkmıştır.

Öğretim elemanlarının örgütsel bağlllık hisleri ile medeni durumları ve kurumlarındaki hizmet süreleri açısından da bir farklılık görülmemiştir. Bu sonuç Belli ve Ekici (2012) tarafindan spor il müdürlüklerinde çalışan personelin örgütsel bağllıklarının araştırıldığı çalışmanın bulgularıyla örtüşmektedir.

Öğretim elemanlarının cinsiyetleri duygusal ve devam bağlliı̆ı alt boyutlarında farklıllğa konu olmuştur. Duygusal bağlllıkta erkek öğretim elemanlarının aritmetik ortalamaları, devam bağlılığında ise kadın öğretim elemanlarının aritmetik ortalamaları yüksek çıkmıştır. Çıkan bu sonuç erkek çalışanların kurumlarından beklentilerinin daha yüksek olmasının bağlılıklarını etkilediği öngörüsü ile açıklanabilir. Yavuz ve Bedük (2016), banka çalışanlarını inceledikleri çalısmalarında, kadın çalışanların örgütsel bağlılıklarının daha yüksek olduğunu bulgulamıştır. Bu sonuç, bu araştırmanın bulgulanı ile zıtlık göstermektedir.

Yaş değişkenine değinildiğinde; devam bağlllı̆̆ boyutunda farklılı̆̆n 20-29 yaş aralığı ile 3039 ve 40-49 yaş aralığ1 arasında oluştuğu görülmüsstür. Bu gruplar arasında en yüksek bağlllık 20-29 yaş aralı̆̆ında tespit edilmiştir. Genç akademisyenlerin bağlllıklarının yüksek düzeyde çıkması, örgütten beklentilerinin henüz yüksek olduğu ve dinamizmleri ile olumsuz koşullara direnç gösterebiliyor olmalarından kaynaklanabilir. Şahin'in (2007) otel işletmelerinde çalışan bireyleri incelediği çalışmasında bağlllı̆ın yaşın ilerlemesiyle arttı̆̆1 görülmüştür. Çıkan sonuç, bu araştırmanın bulguları ile paralellik göstermemektedir.

Katılımciların meslekteki toplam hizmet sürelerine bakıldığında; devam bağlllı̆̆1 alt boyutunda 6-10 yll ile 1-5 yll ve 16-20 yıl grupları arasında farklılıklar tespit edilmiştir. Bu gruplar arasında en yüksek düzeyde bağllık çok yakın ortalama ile 1-5 yıl ve 16-20 yıl olurken, en düşük bağlllığa sahip grup 6-10 yil olmuştur.

Öğretim elemanlarının idari görevi olup olmama değişkeni açısından örgütsel bağllitk düzeyleri karşılaştırıldığında, devam bağlllı̆ı alt boyutu dışında diğer alt boyutlarda istatistiksel olarak anlamlı farkll1ıklara rastlanmıştır. Farklılık tespit edilen tüm alt boyutlarda idari görevi bulunan personelin bağlllık düzeyleri daha yüksek çıkmıştır. İdari görevin örgüt içerisinde personelin yetki ve sorumluluk sınırlarının genişlemesine neden olduğu, çalışanlara görev, yetki ve sorumluluk vermenin onların motivasyonlarını yükselttiği ayrıca idari görevde bulunmanın, yönetime etkin katılma ve kabul görme gibi güdüleyici unsurları tetiklemekle birlikte terfi imkânlarını artırmada önemli rol oynadığ1 Frederich Herzberg'in 'Motivasyon-Hijyen Teorisi'nde açıklanmaktadır (Herzberg, 1966'dan akt. Nichols, 2004). Örgütsel bağlllı̆̆1n idari görevi olanlar lehine farklılık göstermesinin tesadüfi olmadığı da bu teori ile açıklanabilir.

Ünvan değişkeni açısından devam bağlllı̆̆1 alt boyutunda; araştırma görevlileri ile yardımc1 doçentler, doçentler ve profesörler arasında anlamlı farklliklar bulunmuş, bu gruplar arasında en yüksek düzeyde bağlıllğa araştırma görevlileri sahipken en düşük bağlllık hissi profesörler seviyesinde görülmüsstür. Son olarak öğretim elemanlarının örgütsel sinizm ile örgütsel bağlllık düzeyleri arasında negatif yönlü bir ilişki bulunmuştur.

Örgütsel sinizm ile örgütsel bağlllı̆̆ın ters yönlü ilişki göstereceği, çalışmanın kuramsal ve kavramsal çerçevesinde beklenen bir sonuçtur. Ayrıca bu sonuç, Yavuz ve Bedük (2016), Yücel ve Çetinkaya (2015) ve Ahmadi’nin (2014) çalışma sonuçları ile paralellik göstermektedir.

\section{ÖNERILLER}

Çalışmadan elde edilen sonuçlar ışı̆̆ında aşağıdaki öneriler getirilebilir.

- Sağlıklı bir örgüt ortamının oluşturulması ve devam ettirilmesi açısından sinizme yol açan etkenlerin doğru şekilde tespit edilmesi ve önleyici tedbirlerin alınması önem arz etmektedir. 
Çalışkan, K., \& Ekici, S. (2017). Spor eğitimi veren yükseköğretim kurumlarındaki öğretim elemanlarının örgütsel sinizm algıları ile örgütsel bağlllıklarının araştırllması. Journal of Human Sciences, 14(2), 1674-1689. doi:10.14687/jhs.v14i2.4485

- Çalışmanın bulgularında da rastlanan bir sonuç olarak; idari görevde bulunanların sinizm seviyelerinin daha düşük olması gerçeği, sinizmi yaşayan ve yaşatanlar olarak iki şekilde ele alınabilmesini mümkün kılmaktadır. Bu açıdan; yukarıdaki öneriye destek olarak kurumlarda yönetim kademesinde bulunanlanın özellikle çalışmalara dâhil edilmesinin yanında, idari görevle yükümlü çalışanların astlarına karşı daha duyarlı, güdüleyici ve verimlilik odaklı yaklaşımları; sorumlu oldukları personelin kişisel gelişimlerini desteklemeleri hem sağlıklı çalışma ortamının tüm personelin motivasyonunu etkilemesi hem de kurumsal başarıyı tetiklemesi gerçeği ile üzerinde durulması gereken bir konudur.

- Örgütsel bağlllık tarafindan bakıldığında; kurum için olumlu bir etkileşim olan bu his, desteklenmesi, güçlendirilmesi ve devam ettirilmesi bakımından, hem çalışanların kişisel gelişim ve performansları açısından hem de kurumun verimliliğine olumlu katkı sağlaması bakımından üzerinde durulması gereken bir konudur.

- Birbirini ters yönde etkileyen değişkenler olarak; örgütsel sinizm ve örgütsel bağlllık iki farklı uca doğru kayan bir yapıdadır. Bu sebeple ters yönlü ilişki göz önünde bulundurulduğunda; örgütsel sinizmin ne kadar azaltılması ve yok edilmesi gayreti içerisinde bulunulursa, örgütsel bağllilkta da o derece gelişme ve ilerleme sağlanabilir.

\section{Kaynakça}

Ahmadi, F. (2014). Örgütsel sinizmin örgütsel bağhllk üzerindeki etkisinin incelenmesi: Atatürk Üniversitesi çalssanlar üzerine bir araștrma. Yayımlanmamış yüksek lisans tezi, Atatürk Üniversitesi, Erzurum.

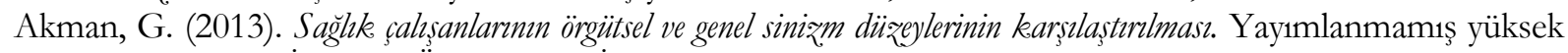
lisans tezi, İstanbul Üniversitesi, İstanbul.

Akyüz, İ. ve Yurduseven, N. O. (2015). Sağllk çalışanlarının örgütsel sinizm düzeylerinin incelenmesi. International Journal of Economic and Administrative Studies, 16, 61-76.

Allen, N. J. ve Meyer, J. P (1990). The measurement and antecedents of affective, continuance, and normative commitment to the organization. Journal of Occupational Psychology, 63, 1-18.

Allen, N. J. ve Meyer, J. P. (1996). Affective, continuance and normative commitment to the organization: An examination of construct validity. Journal of Vocational Behavior, 49, 252-276.

Altınöz, M., Çöp, S., ve Sığındı, T. (2011). Algılanan örgütsel bağlllık ve örgütsel sinizm ilişkisi: Ankara'daki dört ve beş yildızlı konaklama işletmeleri üzerine bir araştırma. Sosyal ve Ekonomik Arastirmalar Dergisi, 15(21), 285-315.

Balay, R. (2000). Özel ve resmi liselerde yönetici ve ögretmenlerin örgütsel bağhllğğ: Ankara ili örneği. Yayımlanmamış doktora tezi, Ankara Üniversitesi, Ankara.

Balay, R., Kaya, A. ve Cülha, A. (2013). Örgüt kültürü ve örgütsel sinizm ilişkisi. Cumburiyet Üniversitesi İktisadi ve İdari Bilimler Dergisi, 14(2), 123-144.

Balıkçıŏlu, S. (2013). Antalya bölgesi konaklama işletmeleri çalısanlarmm örgütsel sinizm tutumlar ile bağllhk ilişkisi üzerine bir araștrma. Yayımlanmamış yüksek lisans tezi, Mustafa Kemal Üniversitesi, Hatay.

Başaran, İ. E. (1991). Örgütsel davranıs: Insanın üretim gücü. Ankara: Gül Yayınevi.

Becker, H. S. (1960). Notes on the concept of commitment. American Journal of Sociology, 66, 32-42.

Belli, E. (2014). Genclik bizmetleri ve spor il müdürlüklerinde çalşan personelin mobbing düzeylerinin araștrrlması ve örgütsel bağhllk yönünden değerlendirilmesi. Yayımlanmamış doktora tezi, Atatürk Üniversitesi, Erzurum.

Belli, E. ve Ekici, S. (2012). Ege bölgesindeki Gençlik Hizmetleri ve Spor İl Müdürlüklerinde çalıssan personelin örgütsel bağlılıklarının araştırılması. Selçuk Üniversitesi Beden Eğitimi ve Spor Bilimleri Dergisi, 14(2), 171-178.

Bolat, T., Seymen, A., Bolat, O. İ. ve Erdem, B. (2009). Yönetim ve Organizasyon. Ankara: Detay Yayıncll1k.

Brandes, P., Dharwadkar, R. ve Dean, J. W. (1999). Does Organizational Cynicism Matter? Employee and Supervisor Perspectives on Work Outcomes. Eastern Academy of Management Proceedings, 150-153.

Çetinkaya, F. F. (2014). Hizmet isletmelerinde psikolojik sözleșme iblalleri ve örgütsel sinizm iliskeisi: Kapadokya bölgesi 4 ve 5 yaldiðl otel işletmelerinde bir araștırma. Yayımlanmamış yüksek lisans tezi, Afyon Kocatepe Üniversitesi, Afyon. 
Çalışkan, K., \& Ekici, S. (2017). Spor eğitimi veren yükseköğretim kurumlarındaki öğretim elemanlarının örgütsel sinizm algıları ile örgütsel bağlllıklarının araştırllması. Journal of Human Sciences, 14(2), 1674-1689. doi:10.14687/jhs.v14i2.4485

Dean, W. J., Brandes, P. ve Dharwadkar, R. (1998). Organizational Cynism. The Academy of Management Review, 23(2), 341-352.

Eaton, J. A. (2000). A social motivation approach to organizational cynicism. Master of arts, York University, Canada.

Efeoğlu, İ. E. ve İplik, E. (2011). Alg1lanan örgütsel adaletin örgütsel sinizm üzerindeki etkilerini belirlemeye yönelik ilaç sektöründe bir uygulama. Cukurova Üniversitesi Sosyal Bilimler Enstitüsï Dergisi, 3, 343-360.

Efilti, S., Gönen, Y. Ö. ve Öztürk, F. Ü. (2008). Örgütsel sinizm: Akdeniz Üniversitesinde görev yapan yönetici sekreterler üzerinde bir alan araştırmas1. 7. Ulusal Büro Yönetimi ve Sekreterlik Kongresi Bildiri Kitabı, Karadeniz Teknik Üniversitesi, Trabzon, 279-290.

Homayouni, V. (2014). Örgütsel bağhllk, iş tatmini ve işten ayrlma ilişkisi: Otel iş̧letmeleri çalışanlar üzerine bir araştrrma. Yayımlanmamış yüksek lisans tezi, Atatürk Üniversitesi, Erzurum.

Kalağan, G. (2009) Araștrma Görevlilerinin Örgütsel Destek. Algzlar İle Örgütsel Sinižn Tutumlarn Arasindaki İliski. Yayımlanmamış yüksek lisans tezi, Akdeniz Üniversitesi, Antalya.

Karademir, M. (2016). Ortaokul ögretmenlerinin okul yönetiminde kayırmachllk alglar ile örgütsel siniż arasindaki iliskkinin incelenmesi: İstanbul ili Pendik ilçesi örneği. Yayımlanmamış yüksek lisans tezi, İstanbul Aydın Üniversitesi, İstanbul.

Karasar, N. (2009). Bilimsel Araştırma Yöntemi. Ankara: Nobel Yayınları.

Nichols, M. (2004). Motivation and Hygiene as a Framework for eLearning Practice. Educational Technology \& Society, 7(3), 1-4.

Özgener, Ş., Öğüt, A. ve Kaplan, M. (2008). "İşgören-İşveren İlişkilerinde Yeni Bir Paradigma: Örgütsel Sinizm”, içinde Özdevecioğlu, M. ve Karadal, H., (Ed.) Örgütsel Davranısta Seçme Konular: Organizasyonlarn Karanhk Yönleri ve Verimlilike. Azaltıcı Davransslar. Ankara: İlke Yayınevi.

Şahin, N. (2007). Personel güçlendirmenin is tatmini ve örgütsel bağhllhk ürerindeki etkisi: Dört ve bes yuldrəh otel işletmelerinde bir uygulama. Yayımlanmamış yüksek lisans tezi, Dokuz Eylül Üniversitesi, İzmir.

Tabachnick, B. G. ve Fidell, L. S. (2013). Using Multivariate Statistics (sixth ed.) Pearson, Boston.

Uygur, A. (2009). Örgütsel Bağhllk. ve İse Bağhllk. Ankara: Barış Platin Kitabevi.

Uzun, T. ve Aylk, A. (2016). Okul müdürlerinin iletişim becerileri ile öğretmenlerin genel ve örgütsel sinizm tutumları arasındaki ilişkilerin incelenmesi. Mersin Üniversitesi Eğitim Fakültesi Dergisi, 12(2), 672-688.

Üreten, Z. K. (2016). Sağlık meslek gruplarının örgütsel sinizm düzeylerini ölçmeye yönelik bir araştırma: Kamu hastanesi ile özel hastane karşılaştırması. Yayımlanmamış yüksek lisans tezi, Marmara Üniversitesi, ,İstanbul.

Yavuz, A. ve Bedük, A. (2016). Örgütsel sinizm ve örgütsel bağlllık arasındaki ilişki: Bir kamu bankasının Konya şubelerinde örnek bir uygulama. Selçuk Üniversitesi Sosyal Bilimler Enstitüsü Dergisi, 35, 301-313.

Yücel, İ. ve Çetinkaya, B. (2015). Örgütsel sinizm ile örgütsel bağlılık arasındaki ilişki ve çalışanlarının yaşının bu ilişki üzerindeki etkisi. "Bazen hoşlanmasak da kalmak zorunda olabiliriz!". Ankara Üniversitesi Sosyal Bilimler Enstitüsü Dergisi, 19(3), 247-271.

\section{$\underline{\text { Extended English Abstract }}$}

\section{Introduction}

Human beings are the key elements of organizations. Communities that cluster for either mutual or similar purposes form organizations. Thus, organizations maintain their continuity through the behaviors of its members in the same way people keep living in their own ways (Başaran, 1991).

The factors leading to the wearing down of employees such as their believing in the lack of justice in matters like wages, promotion and rewarding, the obstacles they face in presenting their talents and skills, intensive work program, lack of communication, role ambiguity or patronage might lead to organizational cynism, which could be described as the negative feelings that employees feel towards the organizations they are attached to (Özgener, Ögüt and Kaplan, 2008: 57).

The opposite of this case is also possible. Commitment of the employees is thought to be one of the key elements in obtaining organizational achievement. Balay (2000) suggests that high-levels of 
Çalışkan, K., \& Ekici, S. (2017). Spor eğitimi veren yükseköğretim kurumlarındaki öğretim elemanlarının örgütsel sinizm algiları ile örgütsel bağlllıklarının araştrilması. Journal of Human Sciences, 14(2), 1674-1689. doi:10.14687/jhs.v14i2.4485

organizational commitment feelings affect not only the personal performance by contributing positively to the development of the employees', but it also provides organizational profit overall.

In order to reduce the level of cynism and achieve a high level of commitment, lectures and conducting scientific research are essential in providing and maximizing societal benefits, with the help of academicians contributing with their own scientific attitudes to education, a pivotal premium in a community. Therefore, in studying and conducting this research, the importance of this fact was taken into consideration.

\section{Methodology}

The population of the study consists of 1572 academic staff from sports sciences departments at higher education institutions, schools of physical education and sports, physical education and sports departments at the faculties of education and the sample of the study consists of 396 sets of data collected from these academic staff.

The scale intended for the participants was prepared and carried out online and it consisted of three parts. The first part included the 7-item personal detail questions aimed at identifying the demographical features of participants.

In the second part, in order to determine the organizational cynism levels of the academic staff, the 13-item “Organizational Cynism Scale," developed by Brandes, Dhalwadkar and Dean was utilized. The reliability test and the Turkish adaptation of the scale was also performed by Kalağan (2009). The 5-item Likert scale included three sub-parts: cognitive, affective and behavioral. The Cronbach alfa internal consistency coefficient was calculated as $\alpha=0.93$ for all the items as tested by Kalağan (2009). Additionally, the sub-parts were calculated as follows: cognitive $\alpha=0.91$, affective $\alpha=0.94$ and behavioral $\alpha=0.86$.

In the third and also the final part of the scale, the organizational commitment levels of the participants were tested through an 18-item Likert scale, which was developed by Allen and Meyer (1996) and adapted to its Turkish format by Belli (2014), was utilized in the study. The $3^{\text {td }}, 4^{\text {th }}, 5^{\text {th }}$ and $13^{\text {th }}$ items of the scale were negative and it involved three sub-parts: cognitive, affective and behavioral. The Cronbach alfa internal consistency coefficient in terms of organizational commitment levels overall was calculated as $\alpha=0.83$ for all the items. Additionally, coefficients of the sub-parts were calculated as follows: affective attachment $\alpha=0.76$, continuity of attachment $\alpha=0.72$ and normative commitment $\alpha=0.77$ (Altınöz, Çöp and Siğınd1, 2011, p.10).

The data were analyzed with SPSS 20.0 packet program. Descriptive statistics were used in order to identify the frequency, percentage and the mean scores achieved from the scale. Since the data were normally distributed, parametric tests were utilized in the study. In order to identify whether there was a significant difference between two independent groups (e.g. gender, marital status, administrative function) t-tests (Independent t-Test) were used. Moreover, for the comparison of more than two groups (e.g. age, the time spent at that occupation, the time spent at that institution, title) analysis of variance (One-Way ANOVA) was used and Tukey HSD test was utilized to specify the groups from which significant differences were derived. Pearson correlation test was also used to examine the relationships between variables. Within the body of this research, all findings were tested with 95\% confidence interval and $\mathrm{p}<0.05$ significance level.

\section{Results and Conclusion}

396 participants out of 1572 academic staff (the population of the study) participated in the study. The participants consisted of 291 males and 105 females. The age range of the majority of the participants was between 30-50 with the percentage of $68.1 \%$. 73.7\% of participants were married and $42.7 \%$ of them were the ones who did not complete their 5-year period at their institutions. The academic staff with administrative duties made up the two thirds of the sample, which equals to $61.4 \%$. Assistant professors participating in the study formed the largest group with the rate of $32.8 \%$.

It was observed that the mean scores of the organizational cynism levels were low, and the organizational commitment was medium-level. The results of the study suggest that the organizational cynism tendency of the participants did not show any significant differences in terms of gender, age, marital status and their time spent at their occupations. However, there were significant differences in terms of the length of time spent working at an institution, particularly between the academic staff who worked from 1 to 5 years and the ones who spent 6 to 10 years at their institutions. It was found out that the academic staff who worked between 6 and 10 years at an institution revealed a higher cynism level. The academic staff with 
Çalışkan, K., \& Ekici, S. (2017). Spor eğitimi veren yükseköğretim kurumlarındaki öğretim elemanlarının örgütsel sinizm algıları ile örgütsel bağlılıklarının araştırlması. Journal of Human Sciences, 14(2), 1674-1689. doi: $10.14687 /$ ihs.v14i2.4485

no administrative duties were found to reveal a high level of cynism overall except for the behavioral cynism sub-dimension. This situation could be associated with the possible element of suppression that may be directed from a higher-level academic staff working at a higher administrative position to a subordinate. When the titles of the academic staff were considered, instructors were found to reveal the lowest cynism perception levels in terms of behavioral cynism sub-dimension whereas the highest cynism perception levels were observed in research assistants and associate professors with the same mean score in both groups.

Additionally, there were no significant differences between the organizational commitment feeling levels of the academic staff and their marital status and time spent at their institutions. These findings show parallels with the findings of the study carried out by Belli and Ekici (2012), which studied the organizational commitment levels of the staff working at sports provincial directorates. Significant differences being considered, the gender of the participants led to a significant difference in the sub-dimensions of affective and continuity commitment levels. The mean scores of the affective commitment levels were high in males whereas the mean scores of the continuity commitment levels were high in females.

When the age variable was considered, there were significant differences in continuity commitment level, particularly between 20-29, 30-39 and 40-49 age groups. The highest commitment levels among these groups were observed in the 20-29 age range. The reason why the younger academic staff showed a higher level of organizational commitment may derive from the fact that they have high expectations from their organizations and they can resist some negative conditions they face with their dynamism.

When the participants' total amount of time spent at their occupations were considered, there were significant differences in continuity commitment level sub-dimension, particularly between the 1-5 years, 610 years and 16-20 years. The highest level of commitment was observed in 1-5 and 16-20 years with very similar results whereas the lowest level of commitment was observed in the group who worked from 6 to 10 years. Apart from the continuity commitment sub-dimension level, it was found out that there were significant differences in academic staff group who had administrative duties. Among all the sub-groups where significant differences were concerned, the commitment levels of the academic staff with administrative duties were higher. Administrative duties are considered to increase the levels of authority and area of responsibility. In addition, assigning duties, authority and responsibilities to the staff is thought to increase the levels of motivation of the academic staff. Having an administrative position in the workplace plays a crucial role in triggering the motivating factors such as taking active part in administration and the feeling of being honored as well as getting promoted. This fact was also explained within the body of Motivation-Hygiene Theory of Frederich Herzberg (Nichols, 2004 qtd. in Herzberg, 1966). With this theory, it can also be claimed that the positive significant difference in terms of organizational commitment is not coincidental. When the title variable of the academic staff was concerned, there were significant differences among research assistants, assistant professors, associate professors and professors. While research assistants were found to show the highest level of commitment, professors revealed the lowest level of commitment. Finally, negative relationship was revealed between the organizational cynism levels and their organizational commitment levels of the participants.

\section{Recommendations}

- The factors leading to cynism should be identified and preventive measures should be taken properly in order to achieve a decent organizational atmosphere and maintain it.

- It should be emphasized that in addition to assigning the academic staff with administrative duties in projects, the staff with higher positions should be sensitive and motivating towards their subordinates with their productivity oriented approaches. Moreover, they should support the personal development of the academic staff they are responsible for. This is an important matter in that these kinds of approaches enhance organizational success and the motivation of the staff.

- Importance should be attached to the fact that tasks should be assigned to the staff squarely and in accordance with the professional competence of the academic staff.

- When organizational commitment is considered, this feeling which is thought to be positive for the organization should be supported, strengthened and maintained so as to contribute positively to the personal development and performances of the staff as well as the productivity levels of the organization. 